ISSN 0258-7122

Bangladesh J. Agril. Res. 37(4): 683-690, December 2012

\title{
GENOTYPIC AND PHENOTYPIC VARIABILITY IN MANGO (Mangifera indica L.)
}

\author{
D. A. N. MAJUMDER ${ }^{1}$, L. HASSAN ${ }^{2}$ \\ M.A. RAHIM ${ }^{3}$ AND M. M. KABIR ${ }^{4}$
}

\begin{abstract}
Sixty mango genotypes were studied to find out their variability, heritability, and genetic advance. Significant variations were observed in 20 characters. There were also considerable differences between the genotypic and the phenotypic coefficients of variation for almost all the characters which indicated the influence of environment on the expression of these traits. Among the studied characters, GCV and PCV were high for weight of harvested fruits per plant, \% fruit harvest per inflorescence, \% initial fruit set per inflorescence, number of fruits per plant and number of main branches per inflorescence. All the characters showed considerably high heritability which ranged from 56.21 to $98.24 \%$ and the genetic advance (as \% of mean) was high for the maximum traits. High heritability coupled with high genetic advance was observed in weight of harvested fruits per plant, \% initial fruit set per inflorescence, \% of flowering shoot, number of inflorescences per shoot, percent fruit harvest per inflorescence, number of main branches per inflorescence, number of fruits per plant, number of inflorescences per shoot, plant height $(\mathrm{cm})$, and percent perfect flowers which indicated that these characters were less influenced by environment confirming predominance of additive gene action and therefore, selection in favour of these characters would be feasible for yield improvement of mango.
\end{abstract}

Keywords: Variability, heritability, genetic advance and mango.

\section{Introduction}

Mango (Mangifera indica L.) is the king of the fruits of Bangladesh. It has got a unique position in respect of nutritional quality, taste, and consumer preference among the fifty kinds of fruits grown in Bangladesh (Ahmad, 1985). In Bangladesh, mango ranks second in area and first in respect of fruit production. According to BBS (2009), Bangladesh produces 600 thousand metric tons of mango from 64 thousand hectares of land.

An understanding of the nature and magnitude of variability among the genetic stocks of a crop is of prime importance to breeders. Evaluation of genetic

\footnotetext{
${ }^{1}$ Manager, Plant Biotechnology Laboratory, BRAC Agricultural Research and Development Centre, Gazipur, ${ }^{2}$ Professor, Dept. of Genetics and Plant Breeding, Bangladesh Agricultural University (BAU), Mymensingh, ${ }^{3}$ Professor, Dept. of Horticulture, BAU, Mymensingh, ${ }^{4}$ Professor, Dept. of Horticulture, Hajee Mohammad Danesh Science \& Technology University (HMDSTU), Dinajpur-5200, Bangladesh.
} 
variability is important to know the source of gene for a particular trait within the available germplasm (Tomooka, 1991). A good knowledge of genetic wealth might also help in identifying desirable cultivars for commercial cultivation. Improvement of yield and other traits depends upon the amount of genetic variability present in the breeding materials for the required traits. High heritability generally enables the breeder to select plants on the basis of the phenotypic expression (Johnson et al., 1955). As the heritability estimates are often subjected to genotype-environment interaction, estimation of genetic advance is required for expected genotypic progress of a particular character. Studies on the variability using genetic parameters are essential for initiating an efficient breeding programme. The present study was an attempt to gather information on genetic variability, heritability, and genetic advance among the important traits of mango crop.

\section{Materials and Method}

The experimental materials comprised of 60 mango genotypes (Table 1). The study was conducted on the pre-established mango orchard of BAU- Germplasm Centre, Department of Horticulture, Bangladesh Agricultural University (BAU), Mymensingh during December to July 2006-2007 and 2007-2008. The experiment was laid out in the RCBD with three replications. The distance from plant to plant was $5 \mathrm{~m}$ and row to row was $5 \mathrm{~m}$. Data were recorded on plant height, leaf area, duration of flowering, percent of flowering shoot, number of inflorescence per shoot, number of main branches per inflorescence, percent perfect flowers, percent fruit set per inflorescence, percent fruit dropping at pea stage, days to maturity (from flowering to harvesting), percent fruit harvest per inflorescence, number of fruits harvested per plant, weight of harvested fruits per plant, fruit weight, fruit length, fruit breadth, fruit thickness, percent edible portion, percent non-edible portion, and percent total soluble solids (TSS). TSS was measured with the help of a hand refractometer. Genotypic and phenotypic coefficient of variation was calculated according to Singh and Chaudhury 1985. Heritability in broad sense $\left(\mathrm{h}^{2} \mathrm{~b}\right)$, genetic advance (GA) and genetic advance in percent of mean (GA \%) were estimated as proposed by Johnson et al. (1955), Hanson et al.(1956), Allard (1960) and Comstock and Robinson (1952), respectively.

\section{Results and Discussion}

Wide range of variation was observed in growth, floral, and different fruit characters of mango which indicated the presence of genetic divergence of the crop (Table 2). Range, mean with standard error, genotypic and phenotypic coefficient of variation, heritability in broad sense and genetic advance in percent mean of some morphological and biochemical traits of mango are presented in Table 3 and Table 4 . The estimates of phenotypic coefficient of variation were 
higher than the genotypic coefficient of variation for all the characters studied. The results indicated the influence of environment on the expression of the characters under investigation.

Table 1. List of mango genotypes along with the source of collection.

\begin{tabular}{|c|c|c|c|c|c|c|c|}
\hline $\begin{array}{l}\text { Sl. } \\
\text { no. }\end{array}$ & $\begin{array}{c}\text { No. of } \\
\text { genotypes }\end{array}$ & Name & $\begin{array}{l}\text { Source of } \\
\text { collection }\end{array}$ & $\begin{array}{l}\text { Sl. } \\
\text { no. }\end{array}$ & $\begin{array}{c}\text { No. of } \\
\text { genotypes }\end{array}$ & Name & $\begin{array}{l}\text { Source of } \\
\text { collection }\end{array}$ \\
\hline 1. & MI 01 & Rad & Philippine & 31. & MI 49 & Totapuri & India \\
\hline 2. & MI 02 & Faraquebhog & Bangladesh & 32. & MI 50 & Kohitoor & India \\
\hline 3. & MI 03 & Anwar-rataul & India & 33. & MI51 & Dudsar & Bangladesh \\
\hline 4. & MI 04 & Shrabani & Bangladesh & 34. & MI52 & Mishridana & Bangladesh \\
\hline 5. & MI 08 & Indian choucha & India & 35. & MI54 & Laxmanghog & Bangladesh \\
\hline 6. & MI 09 & Mallika & India & 36. & MI58 & Samarbehist & India \\
\hline 7. & MI 12 & Pakistani choucha & Pakistan & 37. & MI60 & Kazla-4 & Bangladesh \\
\hline 8. & MI 16 & Tommy Atkins & Florida, USA & 38. & MI61 & Himsagar & Bangladesh \\
\hline 9. & MI 19 & Hybrid-10 & India & 39. & MI64 & Baromashi & Bangladesh \\
\hline 10. & MI 20 & Seedless & India & 40. & MI70 & BARI Aam-4 & Bangladesh \\
\hline 11. & MI 21 & Ratna & India & 41. & MI 74 & Golapkhash & Bangladesh \\
\hline 12. & MI 22 & Mixed special & India & 42. & & Surjapuri & Bangladesh \\
\hline 13. & & & Bangladesh & 43. & & Bandiguri & Bangladesh \\
\hline 14. & MI 24 & Fazli & Bangladesh & 44. & MI 80 & $\begin{array}{l}\text { Khuda- } \\
\text { khirsapat }\end{array}$ & Bangladesh \\
\hline 15. & MI 25 & Langra & Bangladesh & 45. & MI 81 & Elshapatti & Bangladesh \\
\hline 16. & MI 26 & Khirsapat & Bangladesh & 46. & & Kew Sai & Thailand \\
\hline 17. & MI 27 & Ashwina & Bangladesh & 47. & MI 83 & Benishan & FloridaUSA \\
\hline 18. & MI 28 & Amrapali & India & 48. & MI 84 & Kalia & Bangladesh \\
\hline 19. & MI 29 & Carabao & Philippine & 49. & MI 85 & Nam Doc Mai & Thailand \\
\hline 20. & MI33 & Bira & Bangladesh & 50. & MI 86 & Nakfazli & Bangladesh \\
\hline 21. & MI 38 & Suborna & India & 51. & MI88 & $\begin{array}{l}\text { Thai } \\
\text { Kanchamitha }\end{array}$ & Philippine \\
\hline 22. & MI 39 & Jolchhatra & Bangladesh & 52. & MI90 & Bhute bomby & Bangladesh \\
\hline 23. & MI 40 & Rataul & India & 53. & MI91 & Golla & Bangladesh \\
\hline 24. & MI 41 & Anu-kachamitha & Bangladesh & 54. & MI92 & Eshordijuthi & Bangladesh \\
\hline 25. & MI 43 & Phalam & India & 55. & MI93 & Bogla & Bangladesh \\
\hline 26. & MI 44 & Kent & Florida,USA & 56. & MI94 & Polyembryony & Bangladesh \\
\hline 27. & MI 45 & Keitt & Florida, USA & 57. & MI95 & Ranguai & Bangladesh \\
\hline 28. & MI 46 & Palmer & Florida,USA & 58. & MI96 & Golapkhash & Bangladesh \\
\hline 29 & MI 47 & Mishribhog & Bangladesh & 59. & MI97 & MDS (Neeluddin) & India \\
\hline 30. & MI 48 & Sindhi & Pakistan & 60. & MI98 & Khirmon & Bangladesh \\
\hline
\end{tabular}


Table 2. Analysis of variance of 20 characters in mango.

\begin{tabular}{|c|c|c|c|c|c|c|c|c|c|c|c|}
\hline \multirow{2}{*}{$\begin{array}{l}\text { Source of } \\
\text { variation }\end{array}$} & \multirow{2}{*}{$\begin{array}{c}\text { Degrees of } \\
\text { freedom } \\
\text { (df) }\end{array}$} & \multicolumn{10}{|c|}{ Mean sum of squares } \\
\hline & & $\begin{array}{c}\text { Plant height } \\
(\mathrm{cm})\end{array}$ & $\begin{array}{l}\text { Leaf Area } \\
\left(\mathrm{cm}^{2}\right)\end{array}$ & $\begin{array}{c}\text { Duration } \\
\text { of } \\
\text { flowering } \\
\text { (days) }\end{array}$ & $\begin{array}{l}\text { Percent } \\
\text { flowering } \\
\text { shoot }\end{array}$ & $\begin{array}{c}\text { Number of } \\
\text { infloresc- } \\
\text { ences/ } \\
\text { shoot }\end{array}$ & $\begin{array}{c}\text { Number } \\
\text { of main } \\
\text { branches/ } \\
\text { infloresce } \\
\text { nce }\end{array}$ & $\begin{array}{c}\text { Percent } \\
\text { bisexual } \\
\text { flowers }\end{array}$ & $\begin{array}{c}\text { Percent } \\
\text { fruit set/ } \\
\text { infloresce } \\
\text { nce }\end{array}$ & $\begin{array}{c}\text { Percent } \\
\text { fruit } \\
\text { dropping } \\
\text { at pea } \\
\text { stage }\end{array}$ & $\begin{array}{l}\text { Days to } \\
\text { maturity } \\
\text { (days) }\end{array}$ \\
\hline Replication & 2 & 979.91 & 8.36 & 4.36 & 7.07 & 0.04 & 0.26 & 6.09 & 0.32 & 5.98 & 5.54 \\
\hline Treatment & 59 & $24044.30 * *$ & 86.78 ** & $72.10 * *$ & $430.43^{* *}$ & $0.65^{* *}$ & $266.59 * *$ & $23.77 * *$ & $115.40^{* *}$ & $102.20 * *$ & $925.36^{* *}$ \\
\hline Error & 118 & 1113.73 & 11.88 & 7.34 & 11.42 & 0.02 & 1.58 & 2.25 & 1.85 & 14.34 & 100.11 \\
\hline Replication & 2 & 0.08 & 5.97 & 1.52 & 206.67 & 0.12 & 0.22 & 0.19 & 5.72 & 5.72 & 3.18 \\
\hline Treatment & 59 & $3.54 * *$ & $471.74^{* *}$ & $57.56^{* *}$ & $5506.25 * *$ & $2.44^{* *}$ & $5.01 * *$ & $3.36 * *$ & $244.39 * *$ & $244.39 * *$ & $18.69 * *$ \\
\hline Error & 118 & 0.17 & 19.06 & 1.12 & 300.86 & 0.52 & 0.14 & 0.21 & 3.42 & 3.42 & 1.25 \\
\hline
\end{tabular}

** $\mathrm{P}<0.01$ 
Table 3. Estimation of genetic parameters for different vegetative and floral characters of 60 mango genotypes

\begin{tabular}{|c|c|c|c|c|c|c|}
\hline Characters & Range & Mean \pm SE & $\begin{array}{c}\text { GCV } \\
(\%)\end{array}$ & $\begin{array}{l}\text { PCV } \\
(\%)\end{array}$ & $\begin{array}{l}h^{2} b \\
(\%)\end{array}$ & $\begin{array}{c}\text { GA } \\
\text { in \% } \\
\text { mean } \\
(5 \%)\end{array}$ \\
\hline Plant height (cm) & \multicolumn{2}{|c|}{$578.33-211.31356 .66 \pm 19.27$} & 24.51 & 26.24 & 87.28 & 47.18 \\
\hline Leaf area $\left(\mathrm{cm}^{2}\right)$ & $52.59-74.32$ & $60.30 \pm 1.99$ & 8.29 & 10.07 & 67.77 & 14.05 \\
\hline Duration of flowering & $17.67-35.33$ & $24.68 \pm 1.57$ & 18.83 & 21.80 & 74.61 & 33.50 \\
\hline$\%$ of flowering shoot & $24.00-71.33$ & $42.41 \pm 1.95$ & 27.87 & 28.99 & 92.44 & 55.20 \\
\hline No. of Inflorescence / shoot & $1.13-2.77$ & $1.74 \pm 0.08$ & 26.41 & 27.57 & 91.76 & 52.12 \\
\hline No of main branches/inflorescence & $21.57-52.53$ & $30.78 \pm 0.73$ & 30.53 & 30.81 & 98.24 & 62.35 \\
\hline$\%$ perfect flowers & $8.10-19.17$ & $12.07 \pm 0.87$ & 22.24 & 25.53 & 75.94 & 39.93 \\
\hline$\%$ initial fruit et/inflorescence & $9.07-29.27$ & $18.50 \pm 0.79$ & 33.24 & 34.06 & 95.26 & 66.84 \\
\hline$\%$ fruit dropping at pea stage & $69.90-88.43$ & $78.96 \pm 2.19$ & 6.85 & 8.37 & 67.12 & 11.57 \\
\hline Days to maturity & $117.00-178.00$ & $141.07 \pm 5.78$ & 11.76 & 13.73 & 73.32 & 20.74 \\
\hline
\end{tabular}

GCV-Genotypic coefficient of variation $\mathrm{h}^{2} \mathrm{~b}$ - Heritability in broad sense PCV- Phenotypic coefficient of variation GA- Genetic Advance

The higher estimates of genotypic and phenotypic coefficient of variation and medium difference between GCV and PCV were obtained for weight of harvested fruits (40.50\% \& 41.69\%), percent initial fruit set (33.24\% \& 34.06\%), fruit harvest per inflorescence (34.89\% and $37.43 \%$ ), number of fruits per plant (31.72\% and 33.68\%), number of main branches per inflorescence (30.51\% \& $30.81 \%)$, percent flowering shoots $(27.87 \%$ and $28.99 \%)$, number of inflorescence per shoot $(26.41 \%$ and $27.57 \%)$ and plant height $(24.51 \%$ \& 26.24\%) (Table 3 and Table 4) which indicated the presence of environmental effect on these characters and wide scope of improvement through selection.

Estimates were very low for leaf area, days to maturity, percent fruit dropping at pea stage, fruit length and TSS suggesting the very limited scope for improvement of these traits through selection. Ranpise and Desai (2003) found high estimates of phenotypic coefficient of variation and genotypic coefficient of variation in lime for number of fruits per plant, flower twig, tree volume and yield per plant. Prasad and Rao (1989) observed high estimates of genotypic coefficient of variation and phenotypic coefficient of variation in lime for rind thickness, juice weight and juice volume in July crops and high estimates for TSS, fruit weight, and number of seeds in December crops. 
Considerable difference was found between genotypic coefficient of variation (22.24\%) and phenotypic coefficient of variation (25.53\%) indicating high environmental effect upon the expression of percent perfect flowers. The medium estimates of genotypic and phenotypic coefficient of variation were obtained by days to flowering, fruit weight, fruit breadth, fruit thickness, and percent edible portion suggesting a hopeful scope for improvement of these traits through selection.

Table 4. Estimation of genetic parameter for different fruit characters of $\mathbf{6 0}$ mango genotypes.

\begin{tabular}{l|r|r|r|r|c|c}
\hline \multicolumn{1}{c|}{ Characters } & Range & Mean \pm SE & GCV & PCV & $\begin{array}{c}h^{2} \mathrm{~b} \\
(\%)\end{array}$ & $\begin{array}{c}\text { GA in \% } \\
\text { Mean } \\
(5 \%)\end{array}$ \\
\hline Fruit weight (g) & $219.00-365.33$ & $283.36 \pm 10.01$ & 14.70 & 15.92 & 85.20 & 27.95 \\
Fruit length (cm) & $6.86-11.50$ & $8.92 \pm 0.42$ & 9.08 & 12.11 & 56.21 & 14.02 \\
Fruit breadth (cm) & $5.37-10.96$ & $7.19 \pm 0.21$ & 17.72 & 18.45 & 92.22 & 35.05 \\
Fruit thickness (cm) & $5.10-9.71$ & $42.41 \pm 1.95$ & 16.10 & 17.66 & 83.12 & 30.24 \\
\% TSS (Brix) & $16.90-28.26$ & $23.07 \pm 0.65$ & 10.45 & 11.52 & 82.29 & 19.53 \\
\% Edible portion & $45.22-79.83$ & $63.67 \pm 1.07$ & 14.08 & 14.31 & 95.91 & 28.40 \\
\% Non-edible portion & $20.17-54.78$ & $36.33 \pm 1.07$ & 24.67 & 25.19 & 95.91 & 49.77 \\
\%Fruit harvest / & $1.56-5.46$ & $10.71 \pm 0.61$ & 34.89 & 37.43 & 86.92 & 67.02 \\
$\begin{array}{l}\text { Inflorescence } \\
\text { No. of fruits / plant }\end{array}$ & $21.33-60.33$ & $38.64 \pm 2.53$ & 31.72 & 33.68 & 88.69 & 61.53 \\
$\begin{array}{l}\text { Weight of harvested } \\
\text { fruits /plant (kg/plant) }\end{array}$ & $6.33-25.04$ & $10.71 \pm 0.61$ & 40.50 & 41.69 & 94.41 & 81.07 \\
\hline
\end{tabular}

GCV-Genotypic coefficient of variation $h^{2} b$ - Heritability in broad sense

PCV- Phenotypic coefficient of variation GA- Genetic Advance

Although the genotypic coefficient of variation and phenotypic coefficient of variation are the measures of genetic variability however, the amount of genetic gain can be estimated from genotypic coefficient of variation and phenotypic coefficient of variation along with heritability. Swarup and Chougule (1962) suggested that the estimates of genotypic coefficient of variation alone was not sufficient to quantify the amount of variation which is heritable and Burton (1952) inferred that genotypic coefficient of variation effects together with heritability estimates would furnish more reliable information. In the present study, heritability estimates were high for most of the characters viz., plant height (87.28 \%), duration of flowering (74.61\%), percent of flowering shoot (92.44\%), number of inflorescence per shoot (91.76\%), number of main branches per inflorescence (98.24\%), percent perfect flower (75.94\%), percent initial fruit set per inflorescence (95.26\%), fruit weight (85.20\%), fruit breadth ( $92.22 \%$ ), fruit thickness (83.12\%), percent TSS (82.29\%), percent edible portion (95.91\%), 
percent non-edible potion ( $95.91 \%$ ), percent fruit harvest per inflorescence (86.69 \%), number of fruits per plant (88.69\%), and weight of harvested fruits per plant (94.41\%) and moderate estimates for remaining characters. Higher values of heritability indicates that either these were simply inherited characters governed by a few major genes or additive gene effects even if, they were under polygenic control and therefore, selection of these characters would be more effective for improvement (Johnson et al., 1955; Panse , 1957). Ranpise and Desai (2003) observed high values of heritability for fruits per plant, average fruit weight, juice percentage, TSS and acidity. Prasad and Rao (1989) recorded high estimates of heritability in lime for TSS, ascorbic acid, acidity, rind thickness, and fruit volume.

The genetic advance expressed in percent mean was very high for some of the characters, such as weight of harvested fruits per plant $(81.07 \%)$ ), number of main branches per inflorescence (62.35\%), percent flowering shoot $(55.20 \%)$, number of inflorescences per shoot (52.12\%), initial fruit set per inflorescence (66.84 \%) number of fruits per plant (61.53\%), and percent fruit harvested per inflorescence (67.02 \%). It might be due to high range of variation among the genotypes. The characters, such as plant height, percent perfect flowers, duration of flowering, fruit weight, fruit breadth, fruit thickness, percent edible portion, and percent non-edible portion expressed moderate genetic advance. The percentage of heritability was $73.32 \%$ and genetic advance was $20.74 \%$ for days to maturity. These moderate to low values of GCV and PCV indicated to low genetic divergence among the accessions for those mentioned vegetative and floral characters indicating practically little chance for plant selection. There was moderate difference between genotypic (6.85\%) and phenotypic (8.37\%) coefficient of variation on percent fruit dropping at pea stage. The result indicated low environmental influence upon the expression of this character. The heritability of percent fruit dropping at pea stage was also moderate (67.12\%) and genetic advance was low.

The higher values of genetic advance for fruits per plant, yield per plant, tree volume, and flower per twig were reported by Ranpise and Desai (2003). Prasad and Rao (1989) observed moderate values of genetic advance in lime for rind thickness, juice weight, juice volume and fruit volume. Panse (1957) opined that high genetic advance would be obtainable when heritability is chiefly due to dominance and epistasis (non additive gene action), consequently genetic advance would also below.

Heritability and genetic gain (GA) aid in referring valuable conclusion for effective selection based on the phenotypic coefficient of variation (Johnson et al., 1955). The characters having high heritability as well as moderate to high genetic advance and narrow difference between GCV and PCV were found in plant height, percent flowering shoot, number of inflorescences per shoot, percent perfect flower, initial fruit set per inflorescence, fruit weight, fruit breadth, fruit 
thickness, \% edible portion, \% non-edible potion, fruit harvest per inflorescence, number of fruits per plant, and weight of harvested fruits per plant indicate predominance of additive gene action for these characters and these characters would have possibilities of selection towards desired direction.

\section{Acknowledgment}

This research work was financially supported by the Prime-Minister's Advanced Studies and Research Scholarships from the Prime-Minister's Office, Government of the People's Republic of Bangladesh. The authors are also grateful to the authorities of Germplasm Centre, Fruit Tree Improvement Program (FTIP) project funded by SDC for providing materials and necessary facilities to conduct the experiments.

\section{References}

Ahmad, K. U. 1985. The mango in Bangladesh: A symbol of versatility. Proc. Symp. Problems and Prospects of Mango Production in Bangladesh, Dhaka. P.1.

Allard, R. W. 1960. Principles of Plant Breeding. John Willy and Sons. Inc. New York. p.96

BBS. 2009. Monthly Statistical Bulletin, Bangladesh (October, 2009). Agricultural Wing, Bangladesh Bureau of Statistics, Statistics Division, Ministry of Planning, Government of the People's Republic of Bangladesh. P. 60.

Burton, G. W. 1952. Quantitative inheritance in grasses. Proc. $6^{\text {th }}$ Int. Grassld Congr. I. Pp. 277-83.

Comstock, R. E. and H. F. Robinson. 1952. Genetic parameters, their estimation and significance. Proc. $6^{\text {th }}$ Intl. Grassld. Congr. I. pp. 284-91

Hanson, C. H., H. F Robinson and R. E. Comstock. 1956. Biometrical studies in yield in segregating populations of Korean Lespedoza. Agron. J. 48: 268-272.

Jonson, H. W., H. F. Robinson, and R. E. Comstock. 1955. Estimates of genetic and environmental variability in soybeans. Agron. J. 47 (2): 314-318.

Panse, V. G. 1957. Genetics of quantitative characters in relation to plant breeding. Indian J. Genet. 17: 318-328.

Prasad, M. B. N. V. and G. S. P. Rao. 1989. Genetic variability, correlations and pathcoefficient analysis for some morphological and biochemical constituents of acid lime fruit. Scientia Hort. 41: 43-53.

Ranpise, S. A. and U. T. Desai. 2003. Genotypic and phenotypic variability in acid lime (C. aurantifolia Swingle). J. Maharashtra Agric. Univ. 28 (1): 21-23.

Singh, R. K. and B. D. Chaudhury. 1985. Biometrical Methods of Quantitative Genetic Analysis. Kalyani Pub. New Delhi.

Swarup, V. and D. S. Chougule. 1962. Studies on genetic variability in sorghum. I. Phenotypic variability and its heritable components in some quantitative characters towards yield. Indian J. Genet. Pl. Breed. 22: 31-39.

Tomooka, N. 1991. Genetic diversity and landrace differentiation of mungbean (Vigna radiata L. Wilczec), and evaluation of its wild relatives (The subgenus Ceratotropics) as breeding materials. Tech. Bull. Trop. Res. Centre, Ministry of Agriculture Forestry and Fisheries, Japan, 28: 1. 